\title{
金属基板上に形成した $\mathrm{Al}_{2} \mathrm{O}_{3}$ 薄膜のアニール効果*
}

\author{
瀧川 貴稔** · 山中 正策**.五十嵐 廉**
}

（昭和63年 2 月 5 日 受理）

\author{
Annealing Effect on Electric Properties of Aluminum Oxide Films \\ on Metal Substrates \\ Takatoshi TAKIKAWA**, Syosaku YAMANAKA** and Tadashi IGARASHI** \\ (Itami Laboratories, Sumitomo Electric Industries, Ltd. Itami-shi, Hyogo)
}

(Received February 5, 1988)

\section{1. 緒言}

半導体素子の高集積化, 高速化, および信頼性の向上 に対応できる実装材料が求められている，高速動作する 素子を高密度で，かつ，トランスファー樹脂モールドや ガラス封止などの信頼性の高い実装が可能な配線基板と して,セラミック薄膜で金属基材を絶縁被覆した基板を 作製した1).

このような基板は, 組立実装過程で受ける熱に対する 特性の安定性が必要である。

本報では，金属基材に被覆したセラミック絶縁薄膜の 熱安定性について述べる.

\section{2. 試料および実験方法}

金属基材には半導体素子の実装材料として広く用いら れている $\mathrm{Fe}-42 \% \mathrm{Ni}$ 合金圧延板（板厚 $0.25 \mathrm{~mm}$, 表面粗 さ $\left.R_{\max } 0.2 \mu \mathrm{m}\right)$ を用い，七ラミック絶縁薄膜として熱 膨張係数が $\mathrm{Fe}-42 \% \mathrm{Ni}$ 合金に比較的近い酸化アルミ= ウム (以下, $\left.\mathrm{Al}_{2} \mathrm{O}_{3}\right)$ を被覆した.

$\mathrm{Al}_{2} \mathrm{O}_{3}$ 薄膜は高周波 (13.56 MHz) 励起イオンプレー ティング法 ${ }^{2)}$ で形成した。蒸発源に $\mathrm{Al}_{2} \mathrm{O}_{3}$ 焼結体を用 い, 基板温度 $673 \mathrm{~K}$, 酸素圧 $5 \times 10^{-2} \mathrm{~Pa}$, 高周波電力 $100 \mathrm{~W}$, 成長速度 $5 \mathrm{~nm} / \mathrm{s}$ で成膜し, 厚さ $3.5 \sim 8 \mu \mathrm{m}$ と した.

熱安定性を調べるために， $\mathrm{Al}_{2} \mathrm{O}_{3}$ を被覆した基板を $473 \sim 973 \mathrm{~K}$ の大気中で0.6〜 $1.8 \mathrm{ks}$ 間アニールし, 膜構

\footnotetext{
* 昭和62年11月30日 第28回真空に関する連合講演会で講演 $(13 \mathrm{Bp}-4)$
}

** 住友電気工業株式会社伊丹研究所 (兵庫県伊丹市)
造および電気的特性の変化を調べた。

膜構造はX 線回折および透過電子顕微鏡で調べた. 電気的特性として, 絶縁破壊電圧（電界）および電流— 電圧特性を測定した. $\mathrm{Al}_{2} \mathrm{O}_{3}$ 薄膜上に $2 \mathrm{~mm} \square$ の $\mathrm{Al}$ 電極 を蒸着し, 直流電圧を $100 \mathrm{~V}$ ステップで $10 \mathrm{~s}$ 間ずつ印加 して0.1 mA の電流を検知した時の電圧を破壊電圧とし た.

\section{3. 実験 結 果}

\section{$3.1 \mathrm{Al}_{2} \mathrm{O}_{3}$ 薄膜の構造および特性}

$\mathrm{Al}_{2} \mathrm{O}_{3}$ 薄膜のアニール前の特性を Table 1 に示す. 薄 膜の組成は, 焼結体を参照試料とする EPMA 分析の結 果, 化学量論組成に比べやや $\mathrm{Al}$ 濃度が高い。屈折率 $(633 \mathrm{~nm})$ および誘電率 $(1 \mathrm{MHz})$ は，それぞれ1.61お よび約 $7^{3)}$ で, 単結晶より低い値となっている.

Fig. 1 に示す X 線回折図形には回折ピークは見られ ず，結晶相は検出されない。

しかし, Fig. 2 の透過電子顕微鏡組織には直径約 20

Table 1 Properties of aluminum oxide film prepared by r.f. ion plating

\begin{tabular}{c|c}
\hline \hline Composition & 43 at \% Al \\
Structure & $\begin{array}{c}\text { Amorphous } \\
\text { (microcrystalline) }\end{array}$ \\
Refractive index & $1.61(633 \mathrm{~nm})$ \\
Dielectric constant & $\sim 7(1 \mathrm{MHz})$ \\
Dielectric strength & $1 \mathrm{MV} / \mathrm{cm} \mathrm{MIN.}$ \\
Resistivity & $\sim 10^{15} \Omega \cdot \mathrm{cm}$ \\
\hline
\end{tabular}




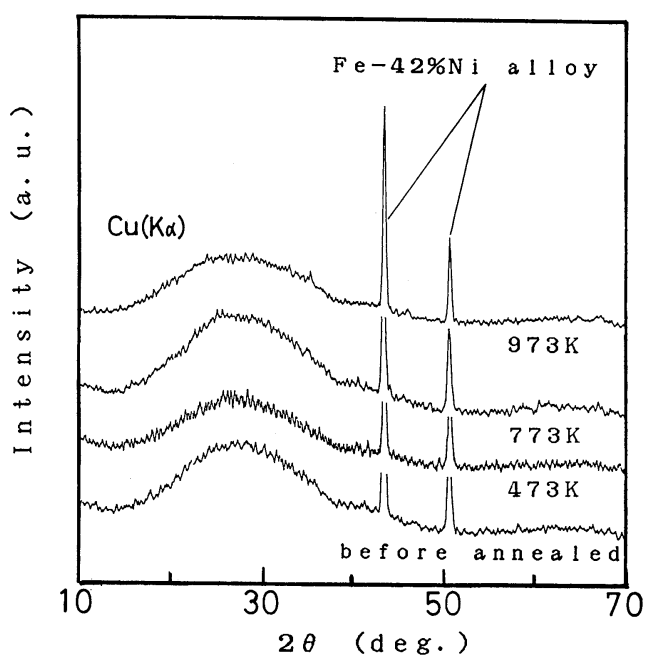

Fig. 1 X-ray diffraction patterns for aluminum oxide films on $\mathrm{Fe}-42 \% \mathrm{Ni}$ alloy substrates.

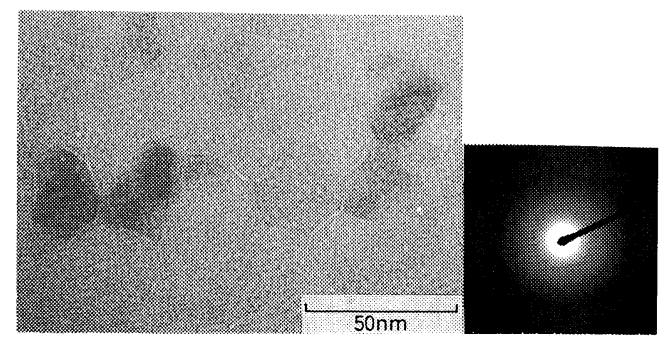

Fig. 2 Microstructure of aluminum oxide film.

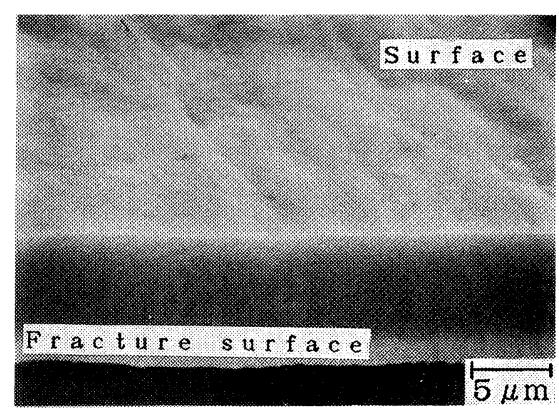

Fig. 3 Surface morpholgy and fracture surface of aluminum oxide film on $\mathrm{Fe}-42 \% \mathrm{Ni}$ alloy substrste.

$\mathrm{nm}$ 程度の粒子が観察され，微結晶相を含む非晶質であ ると考えられる.

Fig. 3 に薄膜の表面および破面の走査型電子顕微鏡組 織を示す，比較的平滑で緻密な薄膜が形成されている.

Fig. 4 に膜厚 $3.8 \mu \mathrm{m}$ の薄膜の絶縁破壞頻度のワイブ

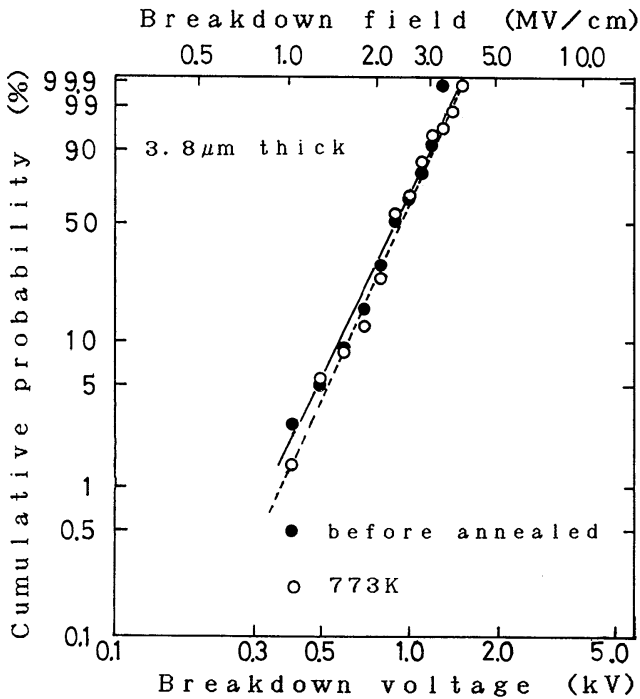

Fig. 4 Dielectric strength of aluminum oxide film on $\mathrm{Fe}-42 \% \mathrm{Ni}$ alloy substrates.

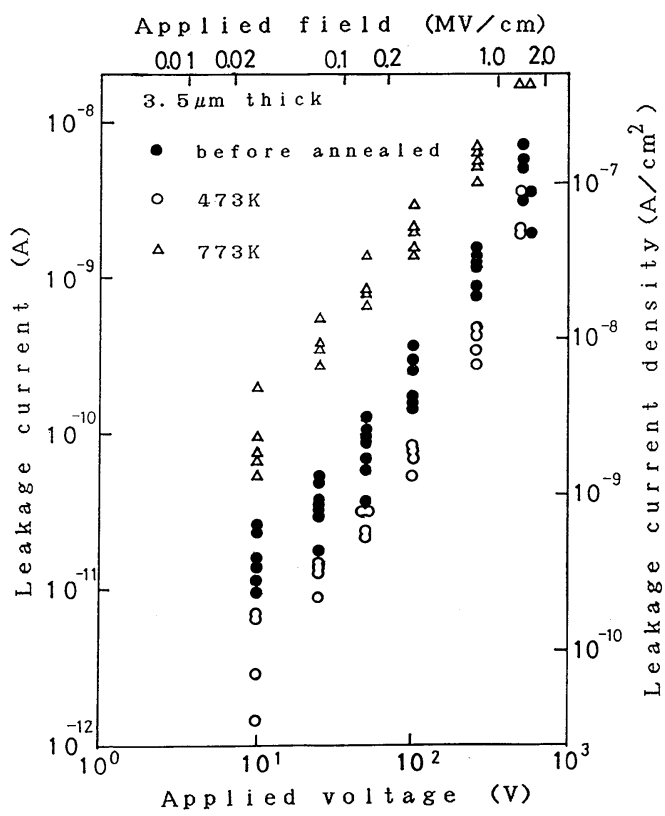

Fig. 5 Leak current (density) - voltage (field) characteristics of aluminum oxide film.

ル分布を示す. $400 \mathrm{~V}$ (1 MV/cm 以上) の破壊電圧が 得られている.

\section{2 アニール効果}

Fig. 1 に, $473 \mathrm{~K} \sim 973 \mathrm{~K}$ で1.8 ks 間アニールした薄膜 の X 線回折図形を示す。いずれの温度においても回折 ピークは見られず, 大きな構造変化は認められない。 
Fig. 4 に絶縁破壊電圧に及ぼすアニールの影響の例と して773 K で0.6 ks 間アニールした後の絶縁破壊頻度の ワイブル分布を示す. $773 \mathrm{~K}$ 以下の温度におけるアニー ルでは絶縁破壞強度にはほとんど变化がおきていない。

Fig. 5 に電流一電圧特性を示す. $473 \mathrm{~K}$ でのアニール によって，リーク電流は減少する傾向にある.

熱処理温度が $773 \mathrm{~K}$ になると, リーク電流は約 1 桁増 大する $\left(\sim 3 \times 10^{-8} \mathrm{~A} / \mathrm{cm}^{2}\right)$ が, $0.15 \mathrm{MV} / \mathrm{cm}(50 \mathrm{~V})$ の 電界に打いて $5 \times 10^{12} \Omega \cdot \mathrm{cm}$ 以上の比抵抗を保持してい る.

\section{4. 結 論}

$\mathrm{Fe}-42 \% \mathrm{Ni}$ 合金圧延板に高周波励起イオンプレーティ ング法で形成した厚さ約 $4 \mu \mathrm{m} の \mathrm{Al}_{2} \mathrm{O}_{3}$ 薄膜の電気的特 性は, $773 \mathrm{~K}$ ま゙のアニールに対して次のような特徵を
持っている.

(1) アニール前後における絶縁破壊電圧の変化はほと んど無く，400 V $(1 \mathrm{MV} / \mathrm{cm})$ 以上の破壊電圧を有 し, $5 \times 10^{12} \Omega \cdot \mathrm{cm}$ 以上の比抵抗を保持寸る.

(2) $473 \mathrm{~K}$ に拈けるアニールでリーク電流は低減され, 絶縁性が向上する.

（3）電流一電圧特性は, 絶縁破壞電圧特性に比べてア ニールに対して敏感であり，何らかの膜構造変化が 起こっていると考えられる.

\section{[文献 $]$}

1）五十嵐, 山中, 井原, 前田, 瀧川：住友電気, No, 131 (1987) 157.

2) 村山, 松本, 柏木: 応用物理, 43 (1974) 687 .

3）井原, 瀧川, 前田, 山中, 五十嵐：信学技報 CPM87-36 (1987). 